\title{
PROBLEMATIKA PARTISIPASI POLITIK PILKADA PROVINSI JAWA TENGAH
} TAHUN 2013

\author{
Solkhah Mufrikhah ${ }^{1}$ \\ Solkhah.mufrikhah@walisongo.ac.id ${ }^{1}$
}

\begin{abstract}
Abstrak: Pilkada merupakan instrumen penting dalam menumbuhkan kehidupan demokratis di tingkat lokal. Dalam Pilkada, satu hal yang menjadi titik perhatian adalah partisipasi politik. Hanya saja, yang patut mendapatkan perhatian adalah bahwa tingkat partisipasi politik masyarakat masih rendah, khususnya yang terjadi di Pilkada Jawa Tengah tahun 2013. Faktor-faktor yang menyebabkan rendahnya partisipasi poitik masyarakat dalam Pilkada Provinsi Jawa Tengah tahun 2013 antara lain masalah yang ada pada diri masyarakat pemilih (internal) dan institusional (eksternal pemilihan). Dengan melihat kondisi di atas, diperlukan sebuah formula kebijakan untuk mempermudah masyarakat agar mau berpartisipasi memberikan hak suaranya di saat Pilkada, serta dorongan kepada masyarakat agar mau berpartisipasi secara substantif.
\end{abstract}

Kata kunci: partisipasi politik, pilkada, Jawa Tengah.

\section{PENDAHULUAN}

Pilkada merupakan instrumen esensial dalam meningkatkan kualitas demokrasi lokal di Indonesia, maka keberadaan Pilkada berkualitas adalah sebuah tujuan. Menyelenggarakan Pilkada yang berkualitas bukanlan pekerjaan yang mudah. Terdapat beberapa pra-kondisi yang harus ada. Dalam segi prosesnya, Pilkada harus dilaksanakan secara adil dan bebas, sedangkan dalam segi outputnya

Pilkada harus dapat melahirkan pemimpin-pemimpin daerah yang demokratis dan responsif pada kepentingan publik. Guna menghasilkan pemimpin daerah yang demokratis dan responsif tersebut, partisipasi politik masyarakat (voters turnout) dalam Pilkada adalah satu hal yang esensial untuk mewujudkan pemerintahan yang demokratis.

Dalam konteks Pilkada, partisipasi politik warga di saat pemilihan pun berorientasi pada peningkatan kesejahteraan dan pemberdayaan masyarakat (Agustino 2009: 189). Oleh karena itu, partisipasi politik dalam studi ini tidak sekedar dimaknai sebagai aktivitas warga negara dalam memberikan suaranya pada waktu pemilihan secara prosedural, tetapi harus mewujud dalam bentuk partisipasi subtantif dari _pemilih cerdas ${ }^{6}$ (smart-voters). Dalam artian, pemilih tidak hanya sekedar datang ke TPS (Tempat Pemungutan Suara) untuk mencoblos, namun menjadi pemilih yang dapat menentukan pilihan pada kandidat yang benar, memahami relevansi Pilkada dalam proses demokrasi lokal, signifikansi partisipasi pemilih, hak dan kewajiban pemilih, dan konsekuensi-konsekuensi suara mereka dalam Pilkada terhad

sistem politik dan tata kelola pemerintahan daerah. Harapannya, masyarakat tidak berhenti pada partisipasi dalam memberikan suara pada saat Pilkada dilaksanakan, namum mereka juga akan ikut mengontrol jalannya 
pemerintahan setelah Pilkada. Karena itu, sebagai langkah awal Pilkada adalah momentum penting bagi masyarakat (pemilih) untuk menjalankan hak memilih (berpartisipasi) mereka.

Akan tetapi, dalam perjalanan Pilkada langsung (dan Pemilu) di Indonesia dalam satu dasawarsa ini, terdapat isu penting yang harus mendapat perhatian bersama, yaitu maraknya praktik politik uang dan fenomena goput (golongan putih) dalam Pilkada. Yang pertama, politik uang terjadi secara masif sebagai instrumen untuk mobilisasi suara baik dalam Pilkada maupun dalam Pemilu Legislatif (Hidayat 2009; Aspinall \& Sukmajati 2016). Yang kedua, golput adalah fenomena untuk menyebut rendahnya partisipasi pemilih dalam politik elektoral, apakah itu dalam Pilkada, Pileg ataupun Pilpres.

Salah satu daerah di Indonesia yang memiliki angka golput paling tinggi atau partisipasi pemilih paling rendah adalah Provinsi Jawa Tengah. Hasil Pilkada Gubernur dan Wakil Gubernur Jawa Tengah pada tahun 2008 dan 2013 menunjukkan bahwa angka partisipasi pemilih cukup rendah. Berdasarkan data KPUD Jawa Tengah menjelaskan bahwa pada Pilkada Gubernur dan Wakil Gubernur Jawa Tengah tahun 2008 dari DPT (Daftar Pemilih Tetap) 25,8 juta tercatat 15.116 .390 orang atau 58,46 persen menggunakan hak pilihnya, sementara yang tidak menggunakan hak pilihnya sebanyak 10.739 .152 orang atau 41,54 persen. Adapun pada Pilkada Gubernur dan Wakil Gubernur Jawa Tengah tahun 2013 dari DPT 27,3 juta tercatat 15.261 .268 orang atau 55,37 persen menggunakan hak pilihnya, sementara yang tidak menggunakan hak pilihnya sebanyak 12.165 .373 orang atau 44,27 persen (KPUD Provinsi Jawa Tengah). Berdasarkan hasil Pilkada tersebut, menunjukkan bahwa angka partisipasi masyarakat pada Pilkada 2013 menurun 3,09 persen, dan angka golput naik 2,73 pesen, bila dibandingkan hasil Pilkada 2008.

Merujuk pada konsepsi di atas dapat dijelaskan bahwa tingginya angka golput pada dua kali Pilkada Gubernur dan Wakil Gubernur itu memberikan sinyal adanya masalah dalam perjalanan demokrasi lokal di Jawa Tengah. Dalam konteks pembangunan demokrasi lokal di Indonesia, fenomena terkait rendahnya partisipasi (voters turnout) pemilih pada dua kali Pilkada, yaitu Pilkada 2008 dan 2013 di tingkat Provinsi Jawa Tengah ini harus menjadi agenda yang tidak dapat dikesampingkan untuk memperbaiki proses-proses Pilkada kedepan, khususnya Pilkada 2018 yang akan dilaksanakan dalam waktu dekat.

Dalam konteks demikian, cukup penting kiranya ilmuwan politik untuk memberikan perhatian pada fenomena rendahnya partisipasi pemilih dan tingginya angka golput dalam politik eletoral yang terjadi di Jawa Tengah sebagai upaya untuk mencegah kemunduran demokrasi lokal. Bahwa demokrasi bukan sebuah kebetulan, namun hasil dari proses perjuangan panjang yang harus terus terpelihara dan dipertahankan. Salah satu upaya yang dapat dilakukan untuk menjaga demokrasi lokal adalah dengan cara meningkatkan partisipasi pemilih dalam Pilkada. 
Partisipasi di sini adalah partisipasi subtantif, yaitu partisipasi pemilih dalam memberikan pilihannya secara cerdas dalam momen-momen Pilkada. Upaya ini dilakukan untuk melahirkan pemimpinpemimpin daerah yang legitimate dan responsif pada kepentingan publik dan pro pada agenda-agenda pembangunan demokrasi di Indonesia.

Konsep partisipasi politik memiliki pemaknaan yang berbeda-beda dalam pandangan banyak ahli. Sebagian memaknai partisipasi politik sebagai upaya untuk terlibat secara aktif dalam proses-proses pemilihan seorang pemimpin politik, dan ini adalah pandangan umum dari para sarjana politik yang beraliran liberal, dan pendukung demokrasi liberal prosedural. Sedangkan sebagian yang lain berpandangan bahwa pertisipasi politik tidak sekedar hadir dalam proses-proses pemilihan dan penentuan seorang pemimpin politik. Partisipasi politih dari warga negara harus mewujud dalam bentuk keterlibatan warga negara dalam proses-proses politik lebih tinggi, seperti ikut ambil bagian dalam mengontrol pemerintahan, serta terlibat aktif dalam proses pembutan kebijakan atau keputusan terkait agenda embangunan pemerintah.

Adapun konsep partisipasi politik yang dipahami dan digunakan dalam penelitian ini mencoba untuk menggabungkan kedua pandangan di atas. Dimana partisipasi tidak hanya dimaknai sebagai keterlibatan masyarakat dalam proses pemilihan pemimpin politik (penguasa), namun juga aktif dalam proses-proses pembuatan keputusan dan kebijakan publik. Diantara pandangan para sarjana yang memaknai partisipasi politik dalam konsep ini adalah sebagai berikut.

Sebagai definisi umum, menurut Bidiardjo (2008:367) bahwa partisipasi politik merupakan kegiatan warga negara baik sebagai individu atau komunitas untuk ikut serta secara aktif dalam kehidupan politik, antara lain dengan jalan memilih piminan negara dan secara ngsung atau tidak langsung mempengaruhi kebijakan pemerintah (public policy). Kegiatan ini mencakup kegiatan seperti memberikan suara dalam pemilihan umum, menghadiri rapat

umum, mengadakan hubungan (contacting) atau lobbying dengan pejabat pemerintah atau anggota parlemen, menjadi anggota partai, atau salah satu gerakan sosial dengan direct action-nya.

Sedangkan menurut Herbert Mc Closky bahwa partisipasi politik adalah kegiatan sukarela dari warga masyarakat melalui mana mereka mengambil bagian dalam proses pemilihan penguasa, serta terlibat secara langsung atau tidak langsung dalam proses pembentukan kebijakan umum. Selanjutnya, Huntington dan Nelson berpendapat bahwa partisipasi politik adalah kegiatan warga yang bertindak sebagai pribadi-pribadi, yang dimaksud untuk mempengaruhi pembuatan keputusan politik oleh pemerintah. Partisipasi bisa bersifat individual atau kolektif, terorganisir atau spontan, mantap atau sporadis, secara damai atau kekerasan, legal atau ilegal, efektif atau tidak efektif (Budiardjo 2008:

367-368). Begitu juga Surbakti (2007:

140) berpendapat bahwa partisipasi politik adalah kegiatan dari warga negara biasa 
dalam mempengaruhi proses pembuatan dan pelaksanaan kebijakan umum dan dalam ikut menentukan pemimpin pemerintahan.

Menurut Huntington dan Nelson (1994: 9) bahwa partisipasi politik dapat dibagi menjadi dua, yaitu partisipasi bersifat Otonomi dan Mobilisasi. Partisipasi politik yang bersifat Otonom (Autonomous Participation) yaitu partisipasi politik yang didasarkan pada kesadaran politik setiap warga untuk menentukan pilihan. Partisipasi politik yang bersifat Mobilisasi (Mobilized Participation) yaitu partisipasi politik yang dimobilisasi atau dikerahkan oleh pihak lain. Jadi partisipasi politik otonom dilaksanakan berdasarkan pada kesadaran politik setiap orang tanpa adanya paksaan, ancaman ataupun pengerahan. Partisipasi politik otonom murni muncul atas

dorongan atau kehendak pribadi. Sedangkan partisipasi politik yang dimobilisasi merupakan partisipasi politik yang dilakukan oleh karena dikerahkan. Biasanya partisipasi yang di mobilisasi tidak berdasarkan pada kesadaran pribadi, tetapi terjadi melalui paksaan, ancaman bahkan tindakan kekerasan lainnya dengan maksud mengubah pilihan warga.

Namun demikian, terdapat beberapa faktor yang mempengaruhi seseorang untuk mau berpartisipasi dalam aktivitas politik atau tidak. Menurut Milbrath, sebagaimana di kutip Maran (2001: 156-

157) menyebutkan 4 faktor utama yang mendorong orang untuk berpartisipasi dalam kehidupan politik. Pertama, adanya perangsang, maka orang mau berpartisipasi dalam kehidupan politik. Dalam hal ini minat untuk berpartisipasi dipengaruhi oleh misalnya sering mengikuti diskusi-diskusi politik melalui mass media atau melalui diskusi informal. Kedua, faktor karakteristik pribadi seseorang, orang yang berwatak sosial, yang punya kepedulian besar terhadap problem sosial, politik ekonomi dan lainlainnya biasanya mau terlibat dalam

aktifitas politik. Ketiga, faktor karakteristik sosial seseorang, karakter sosial menyangkut status sosial ekonomi, kelompok ras, etnis dan agama seseorang. Bagaimanapun lingkungan sosial itu ikut mempengaruhi persepsi, sikap, dan perilaku seseorang dalam bidang politik. Orang yang berasal dari lingkungan sosial yang lebih rasional dan menghargai nilainilai seperti keterbukaan, kejujuran, keadilan dan lain-lainnya tentu akan mau juga memperjuangkan tegaknya nilai-nilai tersebut dalam bidang politik. Dan untuk itulah mereka mau berpartisipasi dalam kehidupan politik. Keempat, faktor situasi atau lingkungan politik itu sendiri, lingkungan politik yang kondusif membuat orang dengan senang hati berpartisipasi dalam kehidupan politik.

Dalam lingkungan politik yang demokratis, orang merasa lebih bebas dan nyaman untuk terlibat dalam aktivitas-aktivitas politik ketimbang dalam lingkungan politik yang totaliter. Tetapi meningkatnya jumlah pemberi suara secara dramastis di negaranegara bagian selatan Amerika akhir-akhir ini betul-betul akibat dari adanya registrasi yang rapi dan aktivitas pemberian suara di kalangan golongan rakyat berpenghasilan rendah yang secara tradisional apatis.

Berdasarkan uraian tersebut di atas, maka dapat disimpulkan bahwa faktor- 
INTEGRALISTIK

No.2/Th. XXIX/2018

faktor yang sangat mempengaruhi partisipasi politik adalah tingkat pendidikan, jenis kelamin, status sosial ekonomi seseorang, peran partai politik, aktivitas kampanye, calon-calon/tokoh politik yang memiliki daya tarik pribadi kuat (kharismatis). Selain itu, pendidikan politik juga memiliki pengaruh besar dalam meningkatkan partisipasi warga dalam aktivitas politik, misalnya seperti Pilkada.

\section{METODE PENELITIAN}

Untuk menjawab kedua rumusan masalah penelitian yang diajukan, penelitian ini dilakukan dengan metode Participatory Action Research (PAR). Penelitian yang dimaknai sebagai kegiatan riset yang dilaksanakan secara partisipatif diantara masyarakat warga dalam suatu komunitas atau lingkup sosial yang lebih luas untuk mendorong

terjadinya aksi-aksi transformatif (perubahan kondisi hidup yang lebih baik). Dengan demikian, PAR tidak berhenti pada kegiatan riset semata, namun berlanjut pada pemberdayaan anggota komunitas secara partisipatif untuk melakukan sejumlah aksi demi perbaikan kondisi hidup mereka sendiri, atau dalam konteks riset ini adalah perbaikan tingkat partisipasi masyarakat dalam Pilkada Gubernur dan Wakil Gubernur Jawa Tengah tahun 2018.

\section{HASIL DAN PEMBAHASAN}

\section{Persepsi Masayarakat terhadap Keikutserataanya Dalam Pilkada}

Salah satu perwujudan dari pelaksanaan kedaulatan rakyat dalam rangka penyelenggaraan pemerintahan daerah yaitu diberikan pengakuan kepada rakyat untuk berperan serta secara aktif dalam menentukan wujud penyelenggaraan pemerintahan tersebut. Sarana yang diberikan untuk mewujudkan kedaulatan rakyat tersebut yaitu diantaranya dilakukan melalui kegiatan Pemilihan Kepala daerah (Pilkada). Kegiatan pilkada (local election) juga merupakan salah satu sarana penyaluran hak asasi warga negara yang sangat prinsipil.

Oleh karena itu, dalam rangka pelaksanaan hak-hak asasi warga negara adalah keharusan bagi pemerintah untuk menjamin terlaksananya penyelenggaraan pemilihan kepala daerah sesuai dengan jadwal ketatanegaraan yang telah ditentukan. Sesuai dengan prinsip kedaulatan rakyat di mana rakyatlah yang berdaulat, maka semua aspek penyelenggaraan pemilihan kepala daerah itu sendiri pun harus juga dikembalikan kepada rakyat untuk menentukannya. Adalah pelanggaran terhadap hak-hak asasi apabila pemerintah tidak menjamin terselenggaranya pilkada, memperlambat penyelenggaraan pilkada, ataupun tidak melakukan apa-apa sehingga tidak terselenggara sebagaimana mestinya. Pada hasil temuan, beberapa pemilih menjelaskan bahwa keikutsertaannya pada Pikada 2013 didorong oleh adanya persepsi bahwa mengikuti Pilkada 2013 adalah suatu hak atau kewajiban dari warga negara. Karena itu, dalam momen Pilkada seorang warga negara harus memberikan suaranya dengan cara berpartisipasi dalam Pilkada.

Namun, di sisi lain juga terdapat warga, khususnya perempuan dan 
masyarakat ekonomi lemah, yang berpandangan bahwa partisipasi mereka dalam Pilkada didorong oleh adanya pemberian sejumlah uang dari kandidat. Dalam konteks ini, Pilkada dipandang sebagai momen pesta demokrasi lima tahunan dimana warga dapat mendapatkan insentif langsung dari para pejabat dan politisi melalui apa yang dalam diskursus ilmu politik disebut praktik vote buying atau pembelian suara (Stokes 2007). Praktik ini lazimnya terjadi menjelang masa-masa hari pencoblosan. Secara teoritis dan praktis vote buying dapat menjadi instrumen yang ampuh untuk mengalihkan kepentingan seorang pemilih yang awalnya akan memilih kandidat tertentu. Lebih-lebih bagi pemilih yang belum memiliki kejelasan pilihan (vloating mass) akan sangat mudah untuk dibeli suaranya pada momen-momen politik elektoral.

Selain itu, partisipasi pemilih juga digerakkan oleh ikatan identitas antara pemilih dengan kandidat. Politik identitas ini sejak otonomi daerah telah banyak memainkan peran dalam memobilisasi pemilih untuk memberikan dukungan politik pada seorang kandidat. Namun, dalam konteks Jawa Tengah politik identitas tidak sekental yang terjadi di wilayah-wilayah luar jawa.

Persaingan etnis dalam politik tersebut sampai saat ini masih tampak di banyak daerah di Indonesia, meskipun sedikit mengalami pergeseran seiring semakin berimbangnya pengetahuan dan kemampuan etnis. Pasca reformasi, kondisi politik di banyak daerah menjelaskan kekuatan politik etnis etnis hampir berimbang, meskipun penguasaan jabatan tertentu berdasarkan kelompok etnis, di lingkungan pemerintahan, partai politik hingga pimpinan birokrasi masih terjadi hingga sekarang. Kondisi ini karena dampak politisasi kekuatan etnisitas di masa-masa kampanye, sehingga pasca kampanya proses pengelolaan pemerintahan pun harus dijalankan dengan politik identitas.

Faktor lain yang mendorong seorang pemilih berpartisipasi dalam Pilkada adalah terkait dengan bekerjanya jaringan klientelisme yang dibangun antara seorang kandidat dan pemilih. Jaringan klientelisme ini bukan saja lazim bekerja dalam masyarakat yang hidup di wilayah pertanian dan perkebunan sebagaimana kajian James Scoott, namun di era demokrasi juga bekerja dalam politik elektoral.

Dengan demikian, nampak jelas bahwa banyak faktor yang mendorong seorang pemilih hadir berpartisipasi dalam proses-proses politik dan demokrasi, seperti Pilkada. Diantara faktor itu mencakup adanya kesadaran diri dari masyarakat yang sudah memiliki

pengetahuan akan pentingnya berpartisipasi dalam Pilkada; adanya dorongan dari kekuatan modal ekonomi dalam bentuk politik uang dan vote buying; adanya ikatan politik identitas yang bekerja antara kandidat dan pemilih; dan adanya faktor klientelisme yang bekerja dalam politik elektoral.

\section{Faktor - faktor yang mempengaruhi Rendahnya Partisipasi Pemilih Dalam Pilkada Gubernur dan Wakil \\ Gubernur di Jawa tengah}

Konsep partisipasi politik memiliki pemaknaan yang berbeda-beda dalam 
pandangan banyak ahli. Sebagian memaknai partisipasi politik sebagai upaya untuk terlibat secara aktif dalam

proses-proses pemilihan seorang pemimpin politik, dan ini adalah pandangan umum dari para sarjana politik yang beraliran liberal, dan pendukung demokrasi liberal prosedural. Sedangkan sebagian yang lain berpandangan bahwa pertisipasi politik tidak sekedar hadir dalam proses-proses pemilihan dan penentuan seorang pemimpin politik. Partisipasi politik dari warga negara harus mewujud dalam bentuk keterlibatan warga negara dalam proses-proses politik lebih tinggi, seperti ikut ambil bagian dalam mengontrol pemerintahan, serta terlibat aktif dalam proses pembutan kebijakan atau keputusan terkait agenda pembangunan pemerintah.

Adapun konsep partisipasi politik yang dipahami dan digunakan dalam

penelitian ini mencoba untuk menggabungkan kedua pandangan di atas. Dimana partisipasi tidak hanya dimaknai sebagai keterlibatan masyarakat dalam proses pemilihan pemimpin politik (penguasa), namun juga aktif dalam proses-proses pembuatan keputusan dan kebijakan publik.

\section{Golput}

Dalam konsep partisipasi pemilih yang paling populer hanya dengan kehadiran dalam proses pemilihan terdapat fenomena non-voting. Perilaku non-voting tersebut dimanifestasikan di indonesia terutama juga di jawa tengah dengan berbagai bentuk, diantaranya:

1. Dengan tidak hadirnya seseorang dalam pemungutan suara, hal ini sebagai respon protes atau ketidaksepakatannya terhadap pelaksanaan pilkada;

2. Orang yang hadir dalam pemungutan suara tetapi memilih untuk tidak memberikan suaranya;

3. Orang yang hadir dalam pemungutan suara dan merusak dan memberikan centang di beberapa gambar atau nama;

4. Orang yang tidak berada di tempat pemungutan suara dikarenakan tidak terdaftar dalam DPT tersebut.

Dari sejumlah alasan yang dikemukakan oleh responden warga Kelurahan Krapyak Kota Semarang, kita bisa membagi faktor/ alasan tidak ikut pemilihan (golput) dalam dua kategori besar. Pertama, Faktor Eksternal, yaitu faktor atau alasan tersebut datang dari luar dirinya. Dibagi menjadi kelompok alasan administratif dan alasan teknis. Seorang pemilih tidak ikut memilih karena terbentur dengan prosedur administrasiseperti tidak tahu nama terdaftar dalam daftar pemilih, belum mendapat kartu pemilih atau kartu undangan. Riset ini menemukan:

- Warga tidak memilih karena tidak memiliki kartu pemilih padahal yang bersangkutan masih tercatat sebagai warga dari kelurahan tersebut;

- Warga tidak memiliki KTP ditempat warga tersebut mukim;

- Warga tidak mendapatkan kartu undangan untuk memilih / datang ke tempat pemungutan suara dan alasan administrtif lainnya yang menyebabkan pemilih tidak bisa menggunakan haknya. Alasan ini 
yang banyak mempengaruhi

pemilih untuk tidak hadir ke TPS.

Sedangkan alasan teknis, seseorang memutuskan tidak ikut memilih karena tidak ada waktu untuk memilih sedang ada keperluan, harus ke luar kota di saat hari pemilihan, dikarenakan bekerja di luar kota / luar negeri, banyak juga kaum pelajar atau mahasiswa yang menempuh pendidikan di jakarta dan kota lainya. Waktu yang disediakan hanya satu hari untuk memilih di TPS dinilai tidak sebanding dengan biaya dan jauhnya perjalanan mereka menuju ke tempat pemungutan suara.

Kedua, Faktor Internal yaitu faktor yang bersumber dari diri pemilih sendiri. Ini memiliki kaitan dengan masalah ideologis, keyakinan agama dan pandangan rasional terbatas pemilih. Sikap ini misalnya ditunjukkan dari laku

pemilih yang memutuskan tidak menggunakan haknya karena secara sadar memang memutuskan untuk tidak memilih. Pilkada 2013 dipandang tidak ada gunanya, tidak akan membawa perubahan, atau tidak ada kontestan pilkada jateng 2013 yang disukai. Baik dilihat dari figurnya yang memang tidak mengenal dari sisi latarbelakang ataupun visi misi yang memang tidak diketahui oleh masyarakat. Di sini seseorang memutuskan tidak memilih sebagai bentuk protes atau ketidakpuasan, baik terhadap penyelenggaraan Pemilu mapun calon yang maju dalam pemilu. Ini adalah pilihan rasional terbatas dari para pemilih.

Namun di sisi lain, terdapat kelompok fundamentalis yang menilai Pilkada atau pun pemilu adalah bukan merupakan praktik yang diajarkan agama.
Karena itu, mereka mengambil posisi untuk diam dan tidak melibatkan diri dalam proses-proses politik yang ditentangnya, termasuk memberikan suara dalam politik elektoral seperti Pilkada.

Ketiga, faktor tidak adanya pendidikan politik dan sosialisasi politik yang didapatkan masyarakat selama ini. Masyarakat umumnya melihat bahwa partai politik maupun lembaga penyelenggara pemilu/Pilkada seperti KPUD Jawa Tengah juga tidak hadir di tengah-tengah masyarakat untuk memberikan pendidikan politik yang memadai. Karena itu, banyak warga yang tidak memahami secara baik apa itu signifikansi berpartisipasi dalam Pilkada. Pilkada dalam pandangan umum nimaknai sebagai sirkulasi atau pergantian elit penguasa lima tahunan, tanpa memahami signifikansi Pilkada terhadap agenda pembangunan dan demokrasi

Keempat, faktor lain yang mempengaruhi mengapa masyarakat tidak berpartisipasi dalam Pilkada, diantaranya adalah karena pelaksanaan Pilkada yang dianggap bermasalah. Permasalah itu terkait dengan kredibilitas, akuntabilitas dan kejujuran dalam pelaksanaan Pilkada selama ini. Kondisi pelaksanaan Pilkada yang buruk telah membuat masyarakat apatis untuk mau datang ke TPS memberikan suara mereka pada seorang kandidat tertentu. Ini disebabka adanya kekhawatiran akan dimanfaatkannya suara mereka dalam upaya memenangkan salah satu kandidat.

Kelima, faktor lain yang membuat masyarakat memilih untuk golput dalam Pilkada adalah tidak adanya party-ID pada diri masyarakat. Kondisi ini tidak hanya 
menyebabkan pragmatisme masyarakat dalam politik elektoral, namun juga menyebabkan masyarakat enggan datang ke TPS memberikan suara pada kandidat tertentu, apalagi jika harus meninggalkan pekerjaan mereka. Kondisi ini yang kemudian dimanfaatkan oleh partai politik dan politisi pragmatis untuk memobilisasi mereka melalui instrumen politik uang, atau vote buying. Ini sebagaimana penelitian Muhtadi (2013) bahwa rendahnya partisipasi pemilih dan maraknya praktik politik uang disebabkan rendahnya party ID yang dimiliki masyarakat, yaitu satu pengakuan dari masyarakat pemilih tetang adanya keterikatan antara partai politik dan masyarakat sebagai konstituen.

Dari beberapa faktor di atas menunjukkan bahwa tidak semua pilihan golput itu adalah murni kehendak seorang warga yang memiliki hak pilih. Alasan ketidakhadiraan di TPS seorang warga memiliki beragam alasan. Ini menunjukan bahwa adanya kemungkinan masyarakat yang tidak memakai hak suaranya tetapi tidak bermaksud untuk mengambil tindakan golput.

Kondisi diatas seperti yang dijelaskan oleh Louis Desipio, Natalie Masuoka dan Christopher Stout (2007) mengkategorikan Non-Voter tersebut menjadi tiga ketegori yakni ; (a) Registered Not Voted ; yaitu kalangan warga negara yang memiliki hak pilih dan telah terdaftar namun tidak menggunakan hak pilih, (b) Citizen not Registered ; yaitu kalangan warga negara yang memiliki hak pilih namun tidak terdaftar sehingga tidak memiliki hak pilih dan (c) Non Citizen ; mereka yang dianggap bukan warga negara (penduduk suatu daerah) sehingga tidak memiliki hak pilih.

Dengan melihat kondisi di atas, diperlukan sebuah formula dan kebijakan untuk mempermudah masyarakat agar mau berpartisipasi memberikan hak suaranya di saat Pilkada. Formula ini menjebatani kasus-kasus golput yang desebabkan karena masalah administrasi dan teknis lainnya, seperti kasus warga yang dalam kondisi sedang bepergian, namun dapat dengan mudah dapat memberikan hak suaranya. Selain kita harus memberikan perhatian besar pada

upaya meningkatkan kesadaran masayrakat tentang pentingnya Pilkada melalui pendidikan kritis, ini yang akan didiskusikan pada pembahasan di bab berikutnya.

Satu hal yang perlu dipahami bahwa partisipasi politik masyarakat merupakan salah satu bentuk aktualisasi dari proses demokratisasi. Keinginan ini menjadi sangat penting bagi masyarakat dalam proses pembangunan politik bagi negaranegara berkembang seperti di Indonesia, karena di dalamnya ada hak dan kewajiban masyarakat yang dapat

dilakukan salah satunya adalah berlangsung dimana proses pemilihan kepala negara, gubernur dan wakil gubernur sampai dengan pemilihan walikota dan bupati dilakukan secara langsung. Partisipasi pemilih bisa diukur dari tinggi rendahnya tingkat kehadir pemilih dan ketidakhadiran pemilih ke TPS.

Upaya untuk meningkatkan partisipasi ini bisa dilakukan oleh banyak pihak. Berdasarkan analisis melalui 
banyak kajian dijelaskan bahwa, lembaga sosial dapat menjadi agen yang bekerja mendorong partispasi pemilih dalam Pilkada atau pemilu.

Friedmen dan Hecdter tersebut dalam permasalahan partisipasi politik lembaga sosial mampu memberikan dorongan kepada masyarakat untuk turut berpartisipasi dalam politik. Berdasarkan pengamatan peneliti, lembaga sosial yang turut berperan dalam meningkatkan partisipasi politik masyarakat antara lain adalah KPUD, Partai Politik, Media Massa, dan Ormas. Berikut penjelasan terkait dengan peran masing-masing institusi tersebut.

Pertama, peran KPUD. Dalam UU Nomor 15 tahun 2011 tentang

Penyelenggaraan Pemilihan Umum dijelaskan bahwa sebagai penyelanggara Pemilu KPUD memiliki peran utama meningkatkan partisipasi politik masyarakat khususnya dalam hal menggunakan hak pilihnya. Hal tersebut termuat dalam UU Nomor 15 Tahun 2011 tentang Penyelenggaraan Pemilihan Umum Pasal 10 menyebutkan bahwa: - Salah satu tugas dan wewenang KPU

Kabupaten/Kota adalah menyelenggarakan sosialisasi dan penyelenggaraan Pemilu dan atau yang berkaitan dengan tugas dan wewenang KPU Kabupaten/ Kota kepada masyarakatl. KPUD meningkatkan partisipasi politik masyarkat melalui cara sosialisasi dan pendidikan politik masyarakat. Cara tersebut dilakukan melalui tiga tahapan yakni melalui komunikasi tatap muka, komunikasi melalui media, dan melalui movilisasi sosial.
Kedua, peran Partai Politik. Partai politik dalam UU Nomor 2 tahun 2008 tentang Partai Politik pada pasal 10 disebutkan: - tujuan khusus partai politik adalah meningkatkan partisipasi politik anggota dan masyarakat dalam rangka penyelenggaraan kegiatan politik dan pemerintahan.\| (UU Nomor 2 tahun 2008 tentang Partai Politik).

Selanjutnya dalam pasal 11 dijelaskan: -partai politik berfungsi sebagai sarana pendidikan politik bagi anggota dan masyarakat luas agar menjadi warga Negara Indonesia yang sadar akan hak dan kewajibannya dalam kehiudpan bermasyarakat, berbangsa dan bernegara.l (UU Nomor 2 tahun 2008 tentang Partai Politik). Sosialisasi dan pendidikan politik oleh Partai Politik sedikitnya dilakukan dalam tiga hal, yakni: melalui sosialisasi para kader, pendidikan politik, dan mellaui optimalisasi organisasi sayap partai.

Ketiga, peran media massa. Di era globalisasi seperti saat ini, media memiliki peran yang sangat besar dalam

memberikan informasi kepada masyarakat. Melalui media, komunikasi antara pemerintah dengan masyarakat menjadi lebih mudah. Begitu juga dalam Pemilukada, media menjadi saluran komunikasi yang sangat tepat untuk menyampaikan sosialisasi kepada masyarakat. Sebagai lembaga yang netral, saat ini media menjadi salah satu lembaga yang sangat dipercayai oleh masyarakat. Dengan begitu, dalam peningkatan partisipasi masyarakat media diharapkan mampu memberikan dorongan kepada masyarakat untuk mau menggunakan hak pilinya dalam Pemilukada. Terdapat tiga 
media yang sangat efektif digunakan dalam peningkatan partisipasi politik masyarakat Kabupaten Magetan yaitu: stasiun televise lokal JTV, radio Bagaskara FM, dan koran Jawa Pos.

Keempat, peran Civil Society. Organisasi masyarakat yang banyak bergerak dalam meningkatkan partisipasi politik masyarakat adalah LSM Bangun Magetan Sejahtera dan LSM Magetan Center, Nahdatul Ulama (NU), dan Perguruan Pencak Silat Setia Hati Teratai.

Keempat lembaga sosial tersebut pada intinya memiliki cara yang sama dalam meningkatkan partisipasi politik masyrakat. Yakni melakukan sosialisasi dan memberikan pendidikan politik kepada masyrakat. Dengan melibatkan

banyak lembaga sosial tersebut diharapkan masyarakat dari berbagai elemen terdorong untuk berpartisipasi (Haboddin dan Hakim 2013).

\section{SIMPULAN}

Pembahasan tentang pemetaan masalah yang menyebabkan mengapa partisipasi politik masyarakat di Pilkada 2013 cukup rendah dan angka golput relatif tinggi apabila dibandingkan dengan

Pilkada sebelumnya tahun 2008 ditemuakan adanya serangkaian faktor yang menciptakan fenomena politik itu terjadi. Diantara faktor itu berkaitan dengan masalah yang ada pada diri masyarakat pemilih (internal) dan institusional (eksternal pemiliha).

Faktor internal, yaitu faktor yang bersumber dari diri pemilih sendiri. Ini memiliki kaitan dengan masalah ideologis, keyakinan agama dan pandangan rasional terbatas pemilih.
Faktor kedua, faktor eksternal yang datang di luar kapasitas diri pemilih. Kondisi ini berkaitan dengan buruknya manajerial pelaksanaan Pilkada, seperti kerancuan masalah administrasi kependudukan dan penetapan daftar pemilih tetap (DPT), pengiriman surat suara yang terhambat, ketidak cocokan daftar pemilih dengan alamat pemilih, dan lain sebagainya.

Selain kedua faktor tersebut, tingginya angka golput juga berkaitan dengan faktor tidak adanya pendidikan politik dan sosialisasi politik yang didapatkan masyarakat selama ini. Selain itu, juga berkaitan dengan tidak adanya kepercayaan dari warga terkait dengan

kredibilitas dan akuntabilitas penyelenggaraan Pilkada. Diluar itu, juga terdapat faktor rendahnya party-ID yang ada pada masyarakat. Party-ID ini dapat dibaca bahwa banyak masyarakat yang tidak memiliki ikatan emosional atau pun ideologis dengan sebuah partai politik yang ada di Indonesia.

\section{DAFTAR PUSTAKA}

Agustino, Leo. 2009. Pilkada dan Dinamika Politik Lokal. Yogyakarta: Pustaka Pelajar.

Hidayat, Syarif. 2009. - Pilkada, Money Politics and the Dangers of =Informal Governance'\| dalam Maribeth Erb \& Priyambudi Sulistiyanto ed., Deepening Democracy in Indonesia: Direct Election for Local Leaders (Pilkada). Singapore: ISEAS.

Budiardjo, Meriam. 2008. Dasar-Dasar Ilmu Politik. Jakarta: PT. Gramedia Pustaka. 
INTEGRALISTIK

No.2/Th. XXIX/2018

Surbakti, Ramlan. 2007. Memahami Ilmu Politik, Cet. ke-6. Jakarta: PT. Gramedia Widiasarana Indonesia. Huntington, Samuel P. dan Joan Nelson. 1994. Partisipasi Politik di Negara Berkembang. Jakarta: Rineka Cipta.

Stokes, Susan C. 2007. - Political Clientelism.|l In Carles Boix and
Handbooks of Political Science. New York. Oxford University Press.

Muhtadi, Burhanuddin. 2013. Politik Uang dan Dinamika Elektoral di Indonesia: Sebuah Kajian Awal Interaksi Antara "Party-Id" dan Patron-Klien. Jurnal Penelitian Politik, Volume 10, No. 1 Juni 